\title{
Proceedings
}

\section{Discovery and biochemical characterization of a novel polyesterase for the degradation of synthetic plastics $^{\dagger}$}

\author{
Efstratios Nikolaivits ${ }^{1}$, Phaedra Dimopoulou ${ }^{1}$, Veselin Maslak ${ }^{2}$, Jasmina Nikodinovic-Runic ${ }^{3}$ \\ and Evangelos Topakas ${ }^{1, *}$ \\ 1 Industrial Biotechnology \& Biocatalysis Group, Biotechnology Laboratory, School of Chemical \\ Engineering, National Technical University of Athens, 15780 Athens, Greece; snikolai@chemeng.ntua.gr \\ (E.N.); phaedradim@gmail.com (P.D.) \\ 2 Faculty of Chemistry, University of Belgrade, 11158 Belgrade, Serbia; vmaslak@chem.bg.ac.rs \\ 3 Institute of Molecular Genetics and Genetic Engineering, University of Belgrade, 11000 Belgrade, Serbia; \\ jasmina.nikodinovic@imgge.bg.ac.rs \\ * Correspondence: vtopakas@chemeng.ntua.gr; Tel.: +30-210-772-3158 \\ + Presented at the 1st International Electronic Conference on Catalysis Sciences, 15-30 November 2020; \\ Available online: https://eccs2020.sciforum.net/
}

Published: 10 November 2020

\begin{abstract}
Plastic waste pose an enormous environmental problem contaminating the soil and oceans, due to the release of microplastics that end up in humans through the food web. Enzymatic degradation of plastics has emerged as an alternative to traditional recycling processes. In the present work, we used bioinfomatics tools to discover a gene coding for a putative polyester degrading enzyme (polyesterase). The gene was heterologously expressed, purified and biochemically characterized. Furthermore, its ability to degrade polyethylene terephthalate (PET) model substrates and synthetic plastics was assessed.
\end{abstract}

Keywords: polymer degradation; novel enzyme; plastics

\section{Introduction}

Since the beginning of the large-scale production of plastics in the 1950s, these materials have found a wide variety of applications and became essential in today's society. While in the 1960s, the percentage of plastic waste in municipal solid waste was less than $1 \%$, this number increased to around $10 \%$ in 2005 in countries with middle/high income [1]. The annual production of plastics worldwide was estimated in 2017 to be $348 \mathrm{Mt}, 10 \%$ of which was produced from renewable sources. Almost half of this plastic is channelled to the packaging sector, which contributes greatly to municipal solid waste and marine litter [2]. Abandoned plastic waste poses an enormous environmental problem, contaminating the soil and oceans, killing hundreds of thousands of sea animals. Also, release of microplastic particles, through natural weathering phenomena, can impact the biophysical properties of soil [3].

Even though biodegradable plastics, such as polylactic acid (PLA) and polycaprolactone (PCL), emerged as an eco-friendly solution to the plastic problem, their uncontrollable use and disposal can pose the exact same problems to the already burdened environment, since for instance PLA would take over three decades to biodegrade in soil [4]. Unfortunately, recent studies have highlighted the failure of traditional recycling processes for plastics, as only $9 \%$ of virgin plastic produced out of 8 billion metric tons of oil was recycled [5]. Lately, however, new approaches for recycling of plastics have been proposed, incorporating microorganisms and their enzymes for depolymerization of used plastics and synthesis on new ones. 
Studies dealing the enzymatic degradation of polyesters have been performed for over 15 years. However, since 2016, the discussion about polyethylene terephthalate (PET)-degrading enzymes has bloomed. The turning point was the work of Yoshida et al. (2016) [6], who discovered a PETassimilating bacterium, namely Ideonella sakaiensis. The enzyme responsible for the degradation of the polymer was identified and characterized as a PETase. Up until then, enzymes belonging to the family of cutinases had been studied for PET degradation and especially cutinases from the thermophilic actynomycete bacteria of the genus Thermobifida. IsPETase shares $45-53 \%$ amino acid sequence identity with the actinomycete cutinases. Cutinases have also proven capable of degrading other polyesters (polylactic acid-PLA, polybutylene succinate-PBS, polycaprolactone-PCL) as well [7-10].

Our goal was to discover a novel polyester-degrading enzyme with the ability to hydrolyze both fossil- and bio-based polyesters. The few known PET-degrading enzymes were used as templates for the identification of homologous sequences. The search led to a protein sequence originating from an Antarctic psychrotrophic lipolytic bacterium of the genus Moraxella. This was cloned and expressed in E. coli. The recombinant enzyme was biochemically characterized and its ability to degrade polyesters was tested.

\section{Methods}

\subsection{Cloning and expression of MorEst gene and purification of recombinant enzyme}

Gene coding for the putative polyesterase gene from Moraxella sp. was codon optimized for expression in E. coli and cloned in expression vector pET22b(+). MorEst expression in E. coli BL21 was induced by $0.2 \mathrm{mM}$ isopropyl $\beta$-D-1-thiogalactopyranoside (IPTG) at $16{ }^{\circ} \mathrm{C}$ for $20 \mathrm{~h}$, based on the method described previously [11]. After that time E. coli cells were harvested by centrifugation at $4000 \times \mathrm{g}$ for $15 \mathrm{~min}$ at $4{ }^{\circ} \mathrm{C}$ and resuspended in $50 \mathrm{mM}$ Tris- $\mathrm{HCl} \mathrm{pH} \mathrm{8,300} \mathrm{mM} \mathrm{NaCl} \mathrm{buffer.} \mathrm{Cell}$ suspension was disrupted by sonication during four 1-min cycles ( $8 \mathrm{~s}$ pulses and $5 \mathrm{~s}$ pause) at $40 \%$ amplitude using a $20 \mathrm{kHz}$ high intensity $(400 \mathrm{~W}$ ) ultrasonic processor (VC 400, Sonic \& Materials, Newtown, CT, USA). Cell debris was removed by centrifugation at 20,000 $\times \mathrm{g}, 30 \mathrm{~min}, 4{ }^{\circ} \mathrm{C}$ twice and loaded onto an immobilized metal-ion $\left(\mathrm{Co}^{2+}\right)$ affinity chromatography (IMAC) as described in [12]. The purity of isolated enzymes was checked on SDS-PAGE electrophoresis (12.5\% polyacrylamide) and protein concentration was determined by measuring the absorbance at $280 \mathrm{~nm}$, based on the calculated molar extinction coefficient.

\subsection{Biochemical characterization of recombinant MorEst}

A standard activity assay for MorEst was performed using $p$-nitrophenyl butyrate ( $p$ NPB) as a substrate at $1 \mathrm{mM}$ concentration in $0.1 \mathrm{M}$ phosphate-citrate buffer $\mathrm{pH}$ 6. Reactions were initiated by adding $20 \mu \mathrm{L}$ of enzyme preparation in $230 \mu \mathrm{L}$ of substrate and the release of $p$-nitrophenol was recorded by measuring the absorbance at $410 \mathrm{~nm}$ in a SpectraMax-250 microplate reader (Molecular Devices, Sunnyvale, CA, USA) equipped with SoftMaxPro software (version 1.1, Molecular Devices, Sunnyvale, CA, USA) set at $30^{\circ} \mathrm{C}$.

The effect of temperature and $\mathrm{pH}$ on the activity of MorEst was tested by performing the standard assay by either altering the temperature or the $\mathrm{pH}$ in the range of $20-50{ }^{\circ} \mathrm{C}$ and the $\mathrm{pH} 3-8$. Buffer systems used were phosphate-citrate $\mathrm{pH} 3-6$, sodium phosphate $\mathrm{pH}$ 6-8 and Tris- $\mathrm{HCl} \mathrm{pH} 8$ at a concentration of $0.1 \mathrm{M}$.

The effect of temperature on the stability of MorEst was studied by incubation the enzyme in 20 $\mathrm{mM}$ Tris- $\mathrm{HCl} \mathrm{pH} 8$ buffer at temperatures in the range of $30-50{ }^{\circ} \mathrm{C}$ for up to $8 \mathrm{~h}$ and measuring residual activity by standard assay. The effect of $\mathrm{pH}$ on the stability of MorEst was studied by incubating the enzyme at $4{ }^{\circ} \mathrm{C}$ in $0.2 \mathrm{M}$ of different buffer systems in the range of $\mathrm{pH}$ 5-10 for $24 \mathrm{~h}$ and then measuring residual activity by standard assay. Buffer systems used were citrate-phospate pH 5-6, sodium phosphate $\mathrm{pH}$ 6-8, Tris- $\mathrm{HCl}$ pH 8-9 and Glycine- $\mathrm{NaOH}$ pH 9-10. 
The kinetic characteristics of MorEst were calculated on four different $p$-nitrophenyl fatty-acid esters with varying chain length at standard assay conditions. Esters used were: $p$ NP-acetate $\left(\mathrm{C}_{2}\right)$, $p \mathrm{NPB}\left(\mathrm{C}_{4}\right), p \mathrm{NP}$-octanoate $\left(\mathrm{C}_{8}\right)$ and $p \mathrm{NP}$-decanoate $\left(\mathrm{C}_{10}\right)$.

\subsection{Hydrolysis of PET oligomer, PET and biodegradable polymers}

MorEst ability to degrade plastics was tested in reactions containing $10 \mathrm{mg} \mathrm{mL}^{-1}$ powdered plastic (particle diameter $<500 \mu \mathrm{m}$ ) in $0.1 \mathrm{M}$ phosphate buffer $\mathrm{pH} 7$ incubated at $30^{\circ} \mathrm{C}$ under shacking (1200 rpm) in an Eppendorf Thermomixer Comfort (Eppendorf, Germany) for 3 days. Reactions were initiated by the addition of $25 \mathrm{mg}$ MorEst, while another $12 \mathrm{mg}$ were supplemented 24 and $48 \mathrm{~h}$ later. At the end of the reactions, the residual material was removed by centrifugation, washed with ultrapure water twice, freeze-dried and its weight measured. Polymer materials used were: PET (PAPET clear, Lotte Chemical, UK), PLA (4043D, NatureWorks, USA), polyhydroxy butyrate-PHB (Biomer P226, Biomer, Germany), PCL (CAPA 6500, Ravago Chemicals, Belgium) and PBS (NaturePlast PBE003, NaturePlast, France).

Reactions with PET dimer (ethylene glycol-terephthalic acid- ethylene glycol-terephthalic acid) were performed under the same conditions of temperature and $\mathrm{pH}$ at a substrate concentration of 1 $\mathrm{mg} \mathrm{mL}^{-1}$ for $24 \mathrm{~h}$. These reactions were analyzed on a SHIMADZULC-20AD HPLC equipped with a SIL-20A autosampler. The column used was a C-18 reverse-phase NUCLEOSIL ${ }^{\circledR} 100-5$ (MachereyNagel,Germany) and the mobile phase was $20 \%$ acetonitrile, $20 \% 10 \mathrm{mM}$ sulfuric acid in ultrapure water at a flow rate of $0.8 \mathrm{~mL} \mathrm{~min}^{-1}$. Detection of terephthalic acid (TPA) and its derivatives took place with a photodiode array detector Varian ProStar at $241 \mathrm{~nm}$. Quantification of TPA, mono-(2hydroxyethyl) terephthalate (MHET) and bis(2-Hydroxyethyl) terephthalate BHET was performed by constructing calibration curves with standard concentrations in the range of $0.01-1 \mathrm{mM}$. Prior to analysis $0.1 \% \mathrm{v} / \mathrm{v}$ of $6 \mathrm{M} \mathrm{HCl}$ was added in each reaction and centrifuged at $5000 \mathrm{x} \mathrm{g}, 10{ }^{\circ} \mathrm{C}$. Supernatants were filtered through $0,2 \mu \mathrm{m}$ syringe filters and analyzed.

\section{Results and Discussion}

The selected amino acid sequence, namely MorEst, has been designated as a triacylglycerol lipase by UNIPROT and shares the highest similarity with IsPETase $(45.2 \%)$, followed by the actinomycete cutinases (41.48-46.05\%). A synthetic gene was constructed, optimized for expression in E. coli and cloned in pET22b(+) vector. The native signal peptide of the protein was not included in the gene, instead the pelB signal sequence of the expression vector was utilized for periplasmic localization of the recombinant protein. Expression took place in E. coli BL21 (DE3) after induction with $0.2 \mathrm{mM}$ IPTG at $16^{\circ} \mathrm{C}$ for $20 \mathrm{~h}$. The recombinant protein with an apparent molecular mass of 33 $\mathrm{kDa}$ was functionally expressed in this system and purified using immobilized metal affinity chromatography (IMAC) as seen in Figure 1.

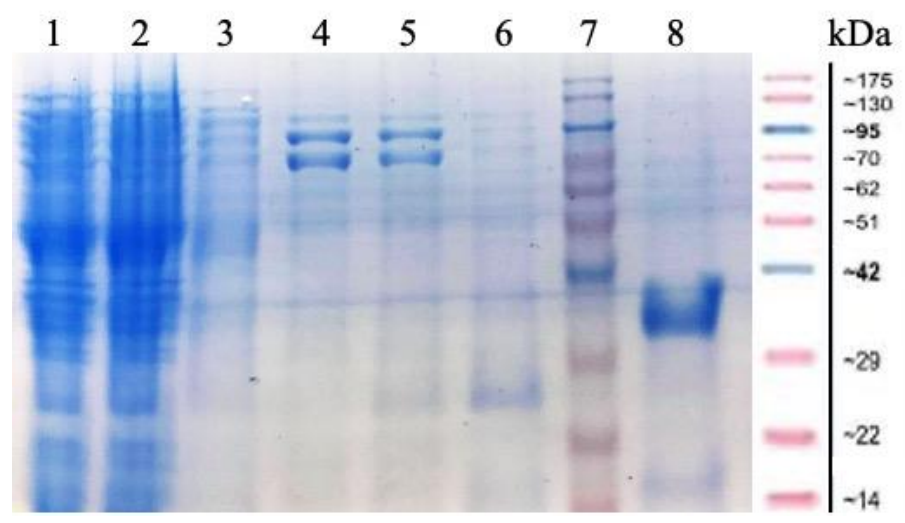

Figure 1. SDS-PAGE gel of IMAC purification steps from the E. coli intracellular fraction after sonication. Lanes: (1) crude intracellular protein fraction; (2) IMAC flow through; (3) washing step; 
elution with (4) $5 \mathrm{mM}$, (5) $10 \mathrm{mM}$ and (6) $20 \mathrm{mM}$ imidazole; (7) protein marker (MWs shown on the right side of the figure); and (8) purified MorEst.

Regarding biochemical characterization, MorEst showed maximum activity at $30{ }^{\circ} \mathrm{C}$, while it maintained over $80 \%$ of its maximum activity in the range of $20-35{ }^{\circ} \mathrm{C}$ (Figure $2 \mathrm{a}$ ). Concerning $\mathrm{pH}$, MorEst seems to act optimally at $\mathrm{pH} 9$, but it showed very high activity at $\mathrm{pH}>7$. However, due to the high autohydrolysis phenomena of $p \mathrm{NPB}$ in alkaline $\mathrm{pH}$ (especially $\mathrm{pH} 9$ ) the results cannot be quantified accurately (Figure 2b).

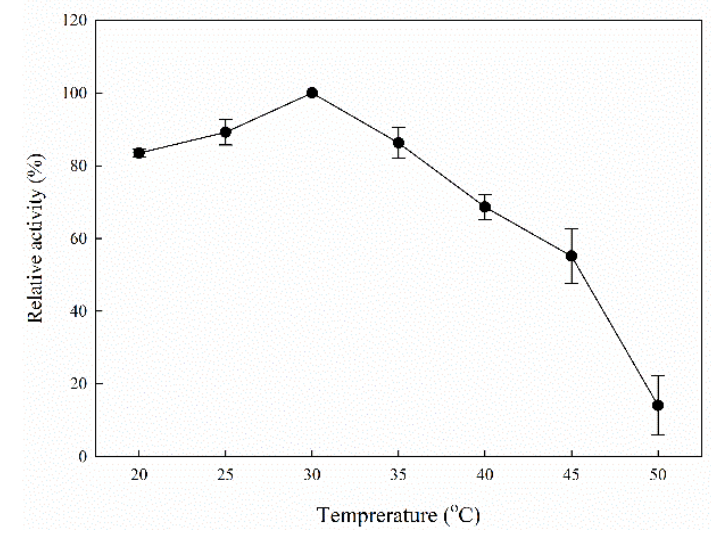

(a)

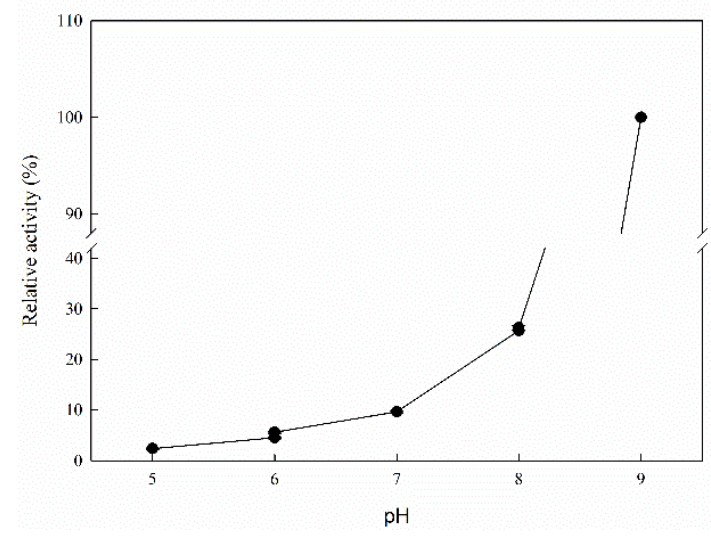

(b)

Figure 2. Effect of temperature (a) and $\mathrm{pH}(\mathrm{b})$ on the activity of MorEst.

MorEst seems to be a rather thermolabile enzyme when incubated in $20 \mathrm{mM}$ Tris- $\mathrm{HCl} \mathrm{pH} 8$ buffer, losing over $90 \%$ of its activity after $1 \mathrm{~h}$ at $50{ }^{\circ} \mathrm{C}$. At $40{ }^{\circ} \mathrm{C}$, half-life of the enzyme was $2 \mathrm{~h}$, while it was more stable at $30{ }^{\circ} \mathrm{C}$, retaining $70 \%$ of its initial activity after $8 \mathrm{~h}$ (Figure 3a). On the contrary, MorEst seemed to be rather stable at different $\mathrm{pH}$ conditions in the range of $\mathrm{pH}$ 5-10 retaining or even enhancing its activity after $24 \mathrm{~h}$ incubation at $4{ }^{\circ} \mathrm{C}$. What was noticed, however, was that the higher salinity of buffer systems (200 mM), was a better environment compared to low (20 mM) salinity systems (Figure 3b).

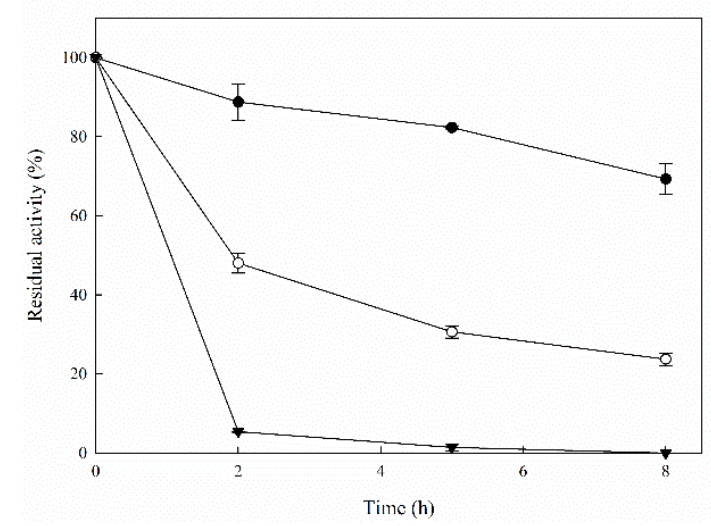

(a)

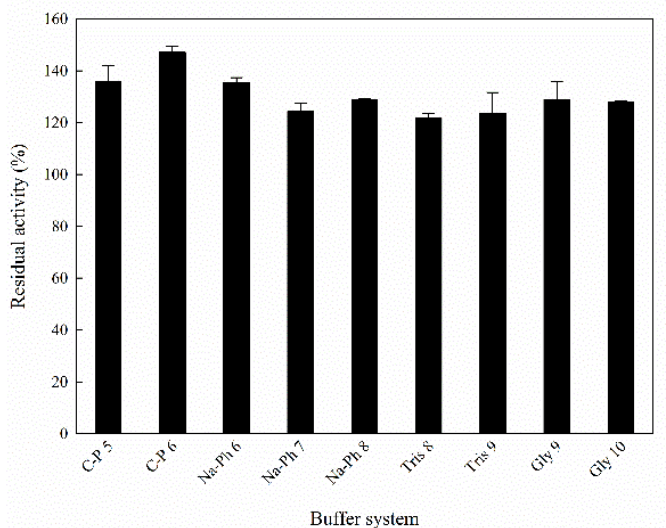

(b)

Figure 3. Effect of temperature (a) and $\mathrm{pH}(\mathrm{b})$ on the stability of MorEst. In (a) relative activity has been calculated based on enzyme incubated in ice, while in (b) enzyme incubated in $20 \mathrm{mM}$ Tris- $\mathrm{HCl}$ pH 8 buffer.

Kinetic constants of MorEst were calculated on different pNP fatty-acid esters with varying chain-length in order to determine the specificity of the enzyme. As seen in Table 1, even though 
MorEst shows the highest catalytic turnover on $p$ NP- $C_{2}$, it shows the highest affinity for $p$ NP- $\mathrm{C}_{4}$, on which it also presents the highest catalytic efficiency. For carbon chain lengths over 8 , the catalytic efficiency of the enzyme drops dramatically (over 20 times).

Table 1. Kinetic constants of MorEst on synthetic substrates.

\begin{tabular}{cccc}
\hline Substrate & $\boldsymbol{k}_{\text {cat }}\left(\mathbf{m i n}^{-1}\right)$ & $\boldsymbol{K M}_{\mathbf{M}}(\mathbf{m M})$ & $\boldsymbol{k}_{\text {cat }} / K_{\mathbf{M}}\left(\mathbf{m i n}^{-1} \mathbf{m M}^{-1}\right)$ \\
\hline$p \mathrm{NP}-\mathrm{C}_{2}$ & $69.6 \pm 7.7$ & $5.4 \pm 1.0$ & $12.8 \pm 2.7$ \\
$p \mathrm{NP}-\mathrm{C}_{4}$ & $29.2 \pm 1.3$ & $1.7 \pm 0.2$ & $17.6 \pm 2.0$ \\
$p \mathrm{NP}-\mathrm{C}_{8}$ & $5.8 \pm 0.7$ & $7.2 \pm 1.1$ & $0.8 \pm 0.2$ \\
$p \mathrm{NP}-\mathrm{C}_{10}$ & $2.7 \pm 0.5$ & $7.0 \pm 1.8$ & $0.4 \pm 0.1$ \\
\hline
\end{tabular}

Recombinant MorEst could cleave soluble BHET producing mostly MHET and a small amount of TPA ( $3 \%$ of total products concentration). It could also hydrolyze the insoluble PET-dimer releasing $1.17 \mathrm{mM}$ TPA and $0.13 \mathrm{mM}$ BHET. However, the enzyme did not release any products of detectable concentration from the crystalline PET polymer tested. Regarding biodegradable polyesters, MorEst showed the highest activity on PCL, reducing its weight by $18 \pm 2 \%$.

\section{Conclusions}

Enzymatic degradation of polymers shows a dynamic as a sustainable solution for the plastic problem faced by modern society. Discovery of novel polymer-degrading enzymes is an important aspect of this solution. In this work we reported the discovery of a novel putative bacterial polyesterdegrading enzyme (polyesterase). The recombinant enzyme was biochemically characterized and its ability to degrade PCL was shown.

Author Contributions: Conceptualization: E.N., E.T.; Methodology: E.N., E.T.; Investigation: E.N., P.D.; Resources: V.M.; J.N.R; E.T.; Writing - Original Draft: E.N.; Writing - Review \& Editing: all; Visualization: E.N.; Supervision: J.N.R., E.T.; Funding acquisition: J.N.R., E.T.

Funding: This research was funded by European Union's Horizon 2020 research and innovation programme under grant agreement No 870292.

Conflicts of Interest: The authors declare no conflict of interest.

\section{References}

1. Almeida, E.L.; Carrillo Rincón, A.F.; Jackson, S.A.; Dobson, A.D.W. In silico screening and heterologous expression of a polyethylene terephthalate hydrolase (PETase)-like enzyme (SM14est) with polycaprolactone (PCL)-degrading activity, From the marine sponge-derived strain Streptomyces sp. SM14. Front. Microbiol. 2019, 10, 2187, doi:10.3389/fmicb.2019.02187.

2. Wei, R.; Breite, D.; Song, C.; Gräsing, D.; Ploss, T.; Hille, P.; Schwerdtfeger, R.; Matysik, J.; Schulze, A.; Zimmermann, W. Biocatalytic degradation efficiency of postconsumer polyethylene terephthalate packaging determined by their polymer microstructures. Adv. Sci. 2019, 6, 1900491, doi:10.1002/advs.201900491.

3. De Souza MacHado, A.A.; Lau, C.W.; Till, J.; Kloas, W.; Lehmann, A.; Becker, R.; Rillig, M.C. Impacts of microplastics on the soil biophysical environment. Environ. Sci. Technol. 2018, 52, 9656-9665, doi:10.1021/acs.est.8b02212.

4. Narancic, T.; O'Connor, K.E. Plastic waste as a global challenge: are biodegradable plastics the answer to the plastic waste problem? Microbiology 2019, 165, 129-137, doi:10.1099/mic.0.000749.

5. Salvador, M.; Abdulmutalib, U.; Gonzalez, J.; Kim, J.; Smith, A.A.; Faulon, J.-L.; Wei, R.; Zimmermann, W.; Jimenez, J.I. Microbial genes for a circular and sustainable bio-PET economy. Genes (Basel). 2019, 10, 
373, doi:10.3390/genes10050373.

6. Yoshida, S.; Hiraga, K.; Takehana, T.; Taniguchi, I.; Yamaji, H.; Maeda, Y.; Toyohara, K.; Miyamoto, K.; Kimura, Y.; Oda, K. A bacterium that degrades and assimilates poly(ethylene terephthalate). Science 2016, 351, 1196-9, doi:10.1126/science.aad6359.

7. Shinozaki, Y.; Kikkawa, Y.; Sato, S.; Fukuoka, T.; Watanabe, T.; Yoshida, S.; Nakajima-Kambe, T.; Kitamoto, H.K. Enzymatic degradation of polyester films by a cutinase-like enzyme from Pseudozyma antarctica: surface plasmon resonance and atomic force microscopy study. Appl. Microbiol. Biotechnol. 2013, 97, 8591-8598, doi:10.1007/s00253-012-4673-0.

8. $\quad \mathrm{Hu}, \mathrm{Z} . ; \mathrm{Wu}$, Y.R.; Lin, B.K.; Maskaoui, K.; Zhuang, D.H.; Zheng, T.L. Isolation and characterization of two phenol-degrading yeast strains from marine sediment. Bull. Environ. Contam. Toxicol. 2006, 76, 899906, doi:10.1007/s00128-006-1003-1.

9. Shi, K.; Su, T.; Wang, Z. Comparison of poly(butylene succinate) biodegradation by Fusarium solani cutinase and Candida antarctica lipase. Polym. Degrad. Stab. 2019, 164, 55-60, doi:10.1016/J.POLYMDEGRADSTAB.2019.04.005.

10. Ping, L.-F.; Chen, X.-Y.; Yuan, X.-L.; Zhang, M.; Chai, Y.-J.; Shan, S.-D. Application and comparison in biosynthesis and biodegradation by Fusarium solani and Aspergillus fumigatus cutinases. Int. J. Biol. Macromol. 2017, 104, 1238-1245, doi:10.1016/J.IJBIOMAC.2017.06.118.

11. Dimarogona, M.; Nikolaivits, E.; Kanelli, M.; Christakopoulos, P.; Sandgren, M.; Topakas, E. Structural and functional studies of a Fusarium oxysporum cutinase with polyethylene terephthalate modification potential. Biochim. Biophys. Acta - Gen. Subj. 2015, 1850, 2308-2317, doi:10.1016/j.bbagen.2015.08.009.

12. Nikolaivits, E.; Kokkinou, A.; Karpusas, M.; Topakas, E. Microbial host selection and periplasmic folding in Escherichia coli affect the biochemical characteristics of a cutinase from Fusarium oxysporum. Protein Expr. Purif. 2016, 127, 1-7, doi:10.1016/j.pep.2016.06.002.

(C) 2020 by the authors. Submitted for possible open access publication under the terms and conditions of the Creative Commons Attribution (CC BY) license (http://creativecommons.org/licenses/by/4.0/). 